\title{
How Can Agricultural Extension and Rural Advisory Services Support Innovation to Adapt to Climate Change in the Agriculture Sector?
}

\author{
M. Kamruzzaman ${ }^{1}$, K.A. Daniell ${ }^{2}$, A. Chowdhury ${ }^{3}$, S. Crimp ${ }^{4}$, H. James ${ }^{5}$
}

\section{Abstract}

Because the climate has been rapidly changing and undermining the sustainability of the agriculture sector, Agricultural Extension and Rural Advisory Services (AERAS) need to rethink their contemporary roles and initiatives. Although enhancing agricultural innovation is considered a key process to increase farm income and ensure sustainability under complex climate-affected development conditions, little is known how AERAS can support the process in the said context. A broad range of literature was reviewed and a deductive coding approach was followed to analyze the literature. The findings suggested numerous transformative roles of AERAS providers supporting agricultural innovation. AERAS providers should extend their mandates and broaden their scopes by connecting and working with multiple actors and groups within and beyond the agriculture sector. They need to support interactions and learning among diversified actors to develop complementary understanding and approaches for collective action for climate change adaptation. The findings highlight the importance of enhancing innovation by AERAS providers for climate change adaptation in the agriculture sector.

\section{Keywords}

Agricultural extension service, agricultural innovation, climate change, extension organization, transformational roles

1. Md Kamruzzaman, Assistant Professor, Sylhet Agricultural University/ PhD Fellow, Australian National University Sylhet-3100, Bangladesh/ ACT 2601, Australia kamruzzamanmd.aext@sau.ac.bd or md.kamruzzaman@anu.edu.au; https://orcid.org/0000-0003-4980-4125

2. Katherine A. Daniell, Associate Professor, Australian National University ANU College of Science, Linnaeus Way, The Australian National University, Acton, ACT 2601, Australia katherine.daniell@anu.edu.au, https://orcid.org/0000-0002-8433-1012

3. Ataharul Chowdhury, Assistant Professor, University of Guelph 50 Stone Road East, Guelph, ON N1G 2W1, Canada ataharul.chowdhury@uoguelph.ca, https://orcid.org/0000-0003-2432-0933

4. Steven Crimp, Research Fellow, Australian National University ANU College of Science, Building 141, Linnaeus Way, The Australian National University, Acton, ACT 2601, Australia steven.crimp@anu.edu.au, https://orcid.org/0000-0003-4068-573X

5. Helen James, Interim Director, Institute for Integrated Research on Disaster Risk Science, Australian National University ANU Research School of Earth Sciences, 142 Mills Road, The Australian National University, Acton, ACT 2601, Australia helen.james@anu.edu.au, https://orcid.org/0000-0001-7169-7691 


\section{Introduction and Problem Statement}

The agriculture sector has been considered extremely vulnerable to climate change with impacts felt across a large number of agricultural land uses (Anita, Dominic, \& Neil, 2010). The primary roles of agricultural extension and rural advisory services (AERAS) have long been recognized as enhancing agricultural development and improving rural livelihoods for both high and low-income countries (Anderson, 2007). In most literature, the terms extension service and advisory service have been used interchangeably, although some literature has used advisory service to highlight the tasks associated with the facilitation of joint learning and action (Faure, Desjeux, \& Gasselin, 2012; Faure et al., 2013). In this article, the term AERAS was used to capture a more comprehensive understanding of roles of service providers and conceptualized as "all the institutions from different sectors that facilitate farmers' access to knowledge, information, and technologies; their interaction with markets, research, and education; and the development of technical, organisational, and management skills and practices" (Davis \& Sulaiman, 2016, p. 1).

The traditional AERAS methods and tools have achieved limited success in tackling the climaterelated challenges in farming (Christoplos, 2010; Selvaraju, 2012). AERAS agencies often do not consider fundamental changes to their conventional strategies and initiatives, and focus on production efficiency, which has been shown to have limited effectiveness in increasing incomes and improving livelihoods (Stål \& Bonnedahl, 2015). As a consequence, a call has emerged to re-think and revise the current AERAS agendas and strategies (Mustapha, Undiandeye, \& Gwary, 2012; Ozor \& Cynthia, 2011). In the context of climate change, enhancing agricultural innovation is likely to be a way to ensure profitable farming and develop the agriculture sector in sustainable ways (Food and Agriculture Organization [FAO], 2018; World Bank, 2012). Although AERAS providers serving as intermediaries and knowledge brokers might fill a significant support role for agricultural innovations to deal with complex issues in general (Rajalahti, Janssen, \& Pehu, 2008), little or only anecdotal evidence exists on how AERAS providers can enhance agricultural innovation for adapting to climate change.

\section{Theoretical and Conceptual Framework}

Climate change is considered a complex problem, having several interrelated drivers and issues (Mahmoudi \& Knierim, 2015). It directly affects certain related sectors, such as agriculture, fishery, and forestry (FAO, 2007). Increasingly, debates are occurring among academic scholars, practitioners, and policymakers about the speed and scale of climate change effects in the agriculture sector (Sala, Rossi, \& David, 2016). It is evident that technical inventions or improvements in practice efficiencies do not suffice as adaptations to climate change in the spheres of natural resource management, cropping, livestock, and forestry. Instead, climate change adaptation should be considered in the light of adjustments of the policy process and institutional systems, which administer crop production, value chains, and consumption strategies (Neufeldt et al., 2015). Successful adaptation to climate change seeks comprehensible sets of technical and institutional initiatives (Leeuwis, Hall, van Weperen, \& Preissing, 2013). In essence, climate change adaptation in the agriculture sector calls to 
support the process of enhancing agricultural innovation (Aase, Chapagain, \& Tiwari, 2013), which is the process whereby:

"Individuals or organizations bring existing or new products, processes, and forms of organization into social and economic use to increase effectiveness, competitiveness, resilience to shocks or environmental sustainability, thereby contributing to food and nutritional security, economic development, and sustainable natural resource management" (Tropical Agriculture Platform, 2016, p. x).

The sources of innovative practices and new ideas are often invisible and primarily contained by a particular actor (Rajalahti et al., 2008). Every actor in a system has both discursive and tacit knowledge (Spielman, Davis, Negash, \& Ayele, 2011). An individual is conscious about discursive knowledge - any idea that can be evaluated and expressed in language.

Nevertheless, individuals are usually unaware of their tacit knowledge, which is embedded in their practical activities, skills, practices, and experiences (Leeuwis, 2004).

The building blocks of innovation are often not accessible because they are the part of individuals' tacit knowledge, and those individuals may not be part of the innovation network (Sharma, Peshin, Khar, \& Ishar, 2014). Initiating new ideas, which draw on both discursive and tacit knowledge, is a process of bringing together the perspectives of multiple actors who have their individual theories of knowing (Ngwenya \& Hagmann, 2011). For enhancing agricultural innovation, therefore, ideas, knowledge, experiences, and creativity from a variety of actors should be connected, integrated, as well as mobilized to ensure collective cognition (World Bank, 2006).

To support agricultural innovation, AERAS providers need to facilitate network building, social learning, and negotiation among relevant actors and groups (Leeuwis \& Aarts, 2011). Network building is critical to establish new relationships among people, technical devices, and natural phenomena. Social learning is required to support individual as well as collective cognitive changes, which may result in conflicts among stakeholders. Therefore, they have to be involved in negotiation to resolve conflicts (Leeuwis, 2004). AERAS agencies have been considered the engine for enhancing agricultural innovation. Given the emerging issues, including climate change, AERAS agencies need to revisit their structures, such as managerial and operational strategies, roles, regulations and cultures and mandates so they can play relevant facilitation and leadership roles in supporting agricultural innovation (Rivera \& Sulaiman, 2009).

In the sections that follow, the establishment of a rationale for the roles of AERAS in enhancing agricultural innovation is explored, particularly in the context of climate change adaptation.

\section{Purpose}

Enhancing agricultural innovation can help individuals and organizations in the agriculture sector to adapt to climate change. But no systematic research exists on what new roles, agendas, and strategies AERAS agencies could undertake to support agricultural innovation. Only a limited number of recent studies have discussed and recommended the roles and 
strategies of AERAS in supporting climate change adaptation. These recommendations are mainly general in nature and based on experts' opinions. In this study, a systematic review of the current literature was undertaken aimed at exploring the mandates and roles of AERAS in supporting agricultural innovation for climate change adaptation.

\section{Methods}

Secondary data was collected by searching in different digital databases, such as Google Scholar, CAB abstract, and Scopus, during the period of March 2018 to August 2019. The searching was bound as only publications in English from 1980 to the present were used. Different keywords were used both separately and in combination to determine relevant literature for analysis. The keywords included adaptation, advisory (rural) services, agricultural extension, agricultural innovation, agricultural practices, climate change, drought, and flood. Articles discussing agricultural practices and the roles of AERAS in adapting to climate change were the focus and principal criteria for inclusion. Peer-reviewed journals, organizational reports, project reports, as well as published and unpublished theses, were selected initially. In addition, national agricultural plans and AERAS strategies of different countries were also included.

A deductive coding of the text was performed using keywords of relevance to agricultural innovation, such as collaboration, connecting, coordination, interaction, learning, linking, negotiation, and networking (Bernard, 2017). Informed by Gough, Oliver and Thomas (2017), the findings were synthesized and presented in a thematic summary. The coded descriptive texts were read through, and specific tasks for AERAS were identified. Those tasks were integrated and interpreted by themes, such as broadening the scope, capacity development, interaction and learning, lobbying policy process and negotiation, performing intermediary roles, and working with multiple actors (Yami, Vogl, \& Hauser, 2009). These themes ultimately supported understanding the processes of enhancing agricultural innovation to adapt to climate change. In the review process, a total of 72 articles were included of which 22 were organizational reports, and 32 were based on empirical research in different countries. In this study, the cases and examples were used according to their significance and relevancy with the themes of agricultural innovation.

\section{Findings}

\section{Broadening the Scope and Working with Multiple Actors}

International organizations (see Table 1) and empirical case studies (see Table 2) reported that the current functions, operational frameworks and strategies of AERAS should be reconsidered and revisited to ensure that agricultural activities are responsive, adaptive, and profitable in the current and future context of climate change. As a consequence, AERAS providers should broaden their scopes and embrace a larger, comprehensive mandate that comprises technical and managerial support, as well as social, gender and institutional governance (Leeuwis et al., 2013; Sala et al., 2016; Simpson \& Burpee, 2014; Sulaiman, Chuluunbaatar, \& Vishnu, 2018). 
The Global Alliance for Climate-Smart Agriculture (GACSA) and United States Agency for International Development (USAID) recommended that AERAS providers should move from a strategy of working with few actors, such as farmers, researchers, to working with multiple and diverse actors and groups from different backgrounds with different knowledge and interests (Sala et al., 2016; Simpson \& Burpee, 2014). Research in Ethiopia found that gaps and missing linkages existed between AERAS providers and other relevant actors while attempting to support adaptation to climate change. Moreover, the policymakers of some AERAS agencies, working at different scales, were in disagreement about the degree of urgency and priority of climate change and adaptation (Abegaz \& Wims, 2015). The Cooperative Extension Services of Land Grant institutions in the United States (US) failed to coordinate efforts to identify priority investment for climate change and agricultural activities at regional and state levels. AERAS providers, therefore, faced challenges of dealing with diverse and often conflicting priorities of stakeholders (Wright Morton et al., 2016). AERAS providers of Cameroon had very negligible contact and limited connection with the farmers, which ultimately led to farmers reaching out to other farmers to seek support and guidance for climate change adaptation (Julie, Amungwa, \& Manu, 2017). Infrequent and limited contact with stakeholders also resulted in disputed relationships between farmers and policymakers in Zimbabwe (Huyer \& Nyasimi, 2017).

The Global Alliance for Climate-Smart Agriculture (GACSA) suggested that all public AERAS providers, serving in a particular region, should be well connected. They need to serve collaboratively for better alignment and synchronization of climate change adaptation activities and programs (Sala et al., 2016). AERAS agencies should link and work in partnership with other relevant actors and groups within and beyond the agriculture sector at different scales to allow free flow of climate change adaptation information, knowledge, understanding, and strategies (Abegaz \& Wims, 2015; Simpson \& Burpee, 2014; Sulaiman et al., 2018). A study in Zimbabwe reported a lack of connection and linkage between two sister organizations, i.e. the Ministry of Agriculture, Mechanisation and Irrigation, Development and the Ministry of Environment, Water and Climate who were the key players for supporting climate change adaptation. This study highlighted the importance of institutional collaboration and coordination among agricultural and climate-related institutions, both public and private, including development agencies at the local, national, regional, and international levels (Huyer \& Nyasimi, 2017).

This review identified that emphasis had been placed on polices, roles, and regulations at institutional levels to facilitate a supportive environment for AERAS providers, but they lacked access to different resources. For instance, about $80 \%$ of AERAS providers in Ethiopia claimed that they did not have adequate access to climate change adaptation resources, such as readily available and user-friendly data, policies and strategies, scientific publications, up to date information, as well as reading materials and manuals (Abegaz \& Wims, 2015). AERAS providers in Cameroon identified lack of access to information from the Ministry related to Environment and Disaster Mitigation, leading to a deficiency in climate change engagement activities (Julie et al., 2017). 
Table 1

The Roles of AERAS Providers to Enhance Agricultural Innovation to Adapt to Climate Change: Insights from International Organizations

\begin{tabular}{|c|c|c|c|c|}
\hline Broad Roles & Specific Tasks & $\begin{array}{l}\text { Number } \\
\text { of Cases }\end{array}$ & Organizations & $\begin{array}{l}\text { Example of Key } \\
\text { Sources }\end{array}$ \\
\hline \multirow{5}{*}{$\begin{array}{l}\text { Broadening the } \\
\text { scope, working } \\
\text { with multiple and } \\
\text { diverse actors }\end{array}$} & $\begin{array}{l}\text { Reconsidering the operational frameworks, strategies, } \\
\text { broadening the mandates, and functions }\end{array}$ & 7 & FAO, GACSA \& USAID & $\begin{array}{l}\text { (Sala et al., 2016; } \\
\text { Simpson \& Burpee, 2014; } \\
\text { Suleiman et al., 2018) }\end{array}$ \\
\hline & $\begin{array}{l}\text { Creating alignment and developing collaboration among } \\
\text { public AERAS providers }\end{array}$ & 1 & GACSA & (Sala et al., 2016) \\
\hline & $\begin{array}{l}\text { Partnering with relevant actors and groups of the agriculture } \\
\text { sector at appropriate scales }\end{array}$ & 2 & USAID \& FAO & $\begin{array}{l}\text { (Simpson \& Burpee, } \\
\text { 2014; Sulaiman et al., } \\
\text { 2018) }\end{array}$ \\
\hline & $\begin{array}{l}\text { Dealing with multiple and diverse actors beyond the } \\
\text { agriculture sector }\end{array}$ & 2 & FAO \& GACSA & $\begin{array}{l}\text { (Leeuwis et al., 2013; } \\
\text { Sala et al., 2016) }\end{array}$ \\
\hline & $\begin{array}{l}\text { Implementing policies, programs, including both agricultural } \\
\text { and fund, policy-related stakeholders }\end{array}$ & 1 & IFPRI & (Davis, 2009) \\
\hline \multirow{4}{*}{$\begin{array}{l}\text { Performing } \\
\text { intermediary roles } \\
\text { and supporting } \\
\text { learning }\end{array}$} & Connecting domestic and international markets & 1 & GACSA & (Sala et al., 2016) \\
\hline & Linking farmers with diverse actors & 1 & GACSA & (Sala et al., 2016) \\
\hline & $\begin{array}{l}\text { Organizing participation and facilitating interaction and } \\
\text { social learning among diverse actors and communities }\end{array}$ & 2 & FAO & (Leeuwis et al., 2013) \\
\hline & $\begin{array}{l}\text { Practicing technological management (e.g. interactive design } \\
\& \text { experimentation; trying out new practices \& adaptive } \\
\text { measures) }\end{array}$ & 7 & $\begin{array}{l}\text { FAO, GFRAS, IFPRI, } \\
\text { USAID }\end{array}$ & $\begin{array}{l}\text { (Hachigonta, 2016; Sala } \\
\text { et al., 2016; Simpson, } \\
\text { 2016) }\end{array}$ \\
\hline \multirow{2}{*}{$\begin{array}{l}\text { Lobbying policy } \\
\text { processes }\end{array}$} & Performing lobby and advocacy communication & 2 & FAO \& GACSA & (Sala et al., 2016) \\
\hline & $\begin{array}{l}\text { Seeking out influencing the enabling environment and } \\
\text { developing supportive policies }\end{array}$ & 2 & FAO \& USAID & $\begin{array}{l}\text { (Simpson \& Burpee, } \\
\text { 2014; Sulaiman et al., } \\
\text { 2018) }\end{array}$ \\
\hline $\begin{array}{l}\text { Capacity } \\
\text { development of } \\
\text { AERAS providers }\end{array}$ & $\begin{array}{l}\text { Deepening and broadening knowledge on soft skills related } \\
\text { to co-learning, communication, facilitation, networking, and } \\
\text { dealing with diverse groups; revising training curricula }\end{array}$ & 4 & $\begin{array}{l}\text { FAO, GACSA, IFPRI, } \\
\text { \& USAID }\end{array}$ & $\begin{array}{l}\text { (Davis, 2009; Sala et al., } \\
\text { 2016; Simpson \& Burpee, } \\
\text { 2014; Sulaiman, 2017) }\end{array}$ \\
\hline
\end{tabular}

Note. FAO=Food and Agriculture Organization, GACSA=Global Alliance for Climate-Smart Agriculture, GFRAS=Global Forum for Rural

Advisory Services, IFPRI= International Food Policy Research Institute, USAID= United States Agency for International Development 


\section{Performing Intermediary Roles and Supporting Interactions}

The Food and Agriculture Organization (FAO) identified that AERAS agencies should provide a broader sense of intermediary roles and support participation and interaction among multiple actors (Leeuwis et al., 2013). AERAS providers need to link domestic market products with international trading markets and consumers (Sala et al., 2016). They should connect farmers with diverse actors, including markets, as well as communities, agencies, and institutions to maximize the benefits of information and knowledge (Hachigonta, 2016; Huyer \& Nyasimi, 2017; Sala et al., 2016). AERAS providers need to facilitate diversified stakeholders to interact and share their knowledge and priorities and negotiate to learn from one another to achieve a better and complementary understanding of climate change impacts and adaptation options (Mahmoudi \& Knierim, 2015; Sala et al., 2016). The USAID recommended that AERAS providers should take advantage of modern and advanced Information and Communication Technologies (ICTs) to link different actors, to support communication and interaction, and to develop a feeling of interdependence and synergy in collective action (Simpson \& Burpee, 2014).

Table 2

The Roles of AERAS Providers to Enhance Agricultural Innovation to Adapt to Climate Change: Insights from Empirical Studies in Different Countries

\begin{tabular}{|c|c|c|c|}
\hline Broad Roles & Specific Tasks & Countries & $\begin{array}{c}\text { Example of Key } \\
\text { Sources }\end{array}$ \\
\hline \multirow[t]{2}{*}{$\begin{array}{l}\text { Networking, } \\
\text { collaboration } \\
\text { and } \\
\text { co-learning }\end{array}$} & $\begin{array}{l}\text { Networking \& partnership development, } \\
\text { collaboration \& coordination of AERAS } \\
\text { activities, information \& knowledge } \\
\text { sharing, collaborative research, co- } \\
\text { learning with multiple \& diverse actors }\end{array}$ & $\begin{array}{l}\text { Ethiopia, India, } \\
\text { Malawi, } \\
\text { Namibia, South } \\
\text { Africa, US, } \\
\text { Zimbabwe }\end{array}$ & $\begin{array}{l}\text { (Abegaz \& Wims, } \\
\text { 2015; Huyer \& } \\
\text { Nyasimi, 2017; } \\
\text { Mkisi, 2014) }\end{array}$ \\
\hline & $\begin{array}{l}\text { Access of AERAS providers to resources } \\
\text { (e.g. funding, policies \& strategies, } \\
\text { reading materials, scientific publications, } \\
\text { updated information \& user friendly data) }\end{array}$ & $\begin{array}{l}\text { Cameroon, } \\
\text { Ethiopia, Kenya, } \\
\text { US }\end{array}$ & $\begin{array}{l}\text { (Abegaz \& Wims, } \\
\text { 2015; Ifejika } \\
\text { Speranza, Kiteme, } \\
\text { \& Opondo, 2009; } \\
\text { Julie et al., 2017) }\end{array}$ \\
\hline $\begin{array}{l}\text { Lobbying/ } \\
\text { Advocating }\end{array}$ & $\begin{array}{l}\text { Providing feedback \& supporting policy } \\
\text { processes }\end{array}$ & $\begin{array}{l}\text { Nigeria, } \\
\text { Zimbabwe }\end{array}$ & $\begin{array}{l}\text { (Huyer \& Nyasimi, } \\
\text { 2017; Ozor \& } \\
\text { Cynthia, 2011) }\end{array}$ \\
\hline $\begin{array}{l}\text { Capacity } \\
\text { development } \\
\text { of AERAS } \\
\text { providers }\end{array}$ & $\begin{array}{l}\text { Capacity development of AERAS } \\
\text { providers on technical \& functional } \\
\text { knowledge (e.g. arranging training, } \\
\text { seminars, and workshops; financial } \\
\text { investments; updating course curricula) }\end{array}$ & $\begin{array}{l}\text { Cameroon, } \\
\text { Ethiopia, India, } \\
\text { Malawi, Namibia, } \\
\text { Nigeria, Pakistan, } \\
\text { South Africa, US, } \\
\text { Zimbabwe }\end{array}$ & $\begin{array}{l}\text { (Afful, 2016; } \\
\text { Diehl et al., 2015; } \\
\text { Mkisi, 2014; } \\
\text { Ogunbameru, } \\
\text { Mustapha \& } \\
\text { Idrisa, 2013) }\end{array}$ \\
\hline
\end{tabular}

To formulate adaptation strategies and develop technological innovation, GACSA, Global Forum for Rural Advisory Services (GFRAS), and USAID recommended setting out interactive design 
principles and co-designed experimentation, as well as promotion of farmer-to-farmer extension (Davis, 2009; Hachigonta, 2016; Sala et al., 2016; Simpson, 2016). AERAS providers of South Africa promoted conservation agriculture as a technological innovation but failed to achieve desired outcomes in terms of increasing yields and ensuring sustainability. Therefore, AERAS providers were suggested to participate in adaptive research on conservation agriculture management packages with farmers and scientists (Afful, 2016). Smallholder farmers of Malawi identified that AERAS providers should strengthen farmers' linkage with research institutions to draw support for on-farm adaptive research and develop the best risk management practices in different farming systems (Mkisi, 2014).

\section{Lobbying and Negotiation}

This literature review highlighted that AERAS providers should have strong linkage and effective communication with the policy process to positively influence the enabling environment and develop supportive policies, as well as funding opportunities for climate change adaptation (Leeuwis et al., 2013, Simpson \& Burpee, 2014; Sulaiman et al., 2018). Farmers in Nigeria perceived that AERAS providers were knowledgeable about the local effects of climate change on the agriculture sector because they lived and worked with farmers in the rural areas. AERAS providers, therefore, could more effectively communicate on local climate change effects to their higher authorities during regular official meetings. Thus, the government and other agencies were aware and could develop plans and policies, allocate funding, and implement programs to address the risks and challenges of climate change (Ozor \& Cynthia, 2011). Likewise, the GACSA suggested that AERAS providers should advocate and raise awareness with decision-makers about the importance of funding for climate change adaptation in the agriculture sector (Sala et al., 2016). AERAS providers need to invite and engage with fundingand policy-related stakeholders while implementing different agricultural policies and programs in the field (Davis, 2009).

\section{Capacity Development of AERAS Providers as an Underlying Condition}

AERAS providers should develop new capacities to explicitly support innovation in the agriculture sector to adapt to climate change (Sala et al., 2016). Researchers in Malawi recommended that AERAS agencies should obtain sufficient investment for human resource development and capacity building (Mkisi, 2014). Evidence from Nigeria highlighted the need to develop teaching and training materials addressing the risks and challenges of climate change for AERAS students and providers, respectively (Ogunbameru et al., 2013).

A case study in the US recommended that AERAS providers should receive training to understand both management- and technology-related adaptation strategies, engage in conversations with stakeholders, and participate in co-production of climate change adaptation-related knowledge and strategy (Diehl et al., 2015). In this vein, the Cameroon case reported that AERAS providers need to be provided with seminars and workshops (Julie et al., 2017). According to the FAO, the current knowledge and efficiencies of AERAS providers should be deepened and broadened mostly on soft skills, such as co-learning, communication, facilitation, and networking with diverse groups at different scales (Davis, 2009; Sulaiman, 2017). 


\section{Conclusions, Discussion, and Recommendations}

To enhance innovation for adapting to climate change in the agriculture sector, AERAS providers need to embrace new organizational mandates, agendas, roles, and strategies. They should broaden their scopes by working with multiple actors and groups both within and beyond the agriculture sector. AERAS providers need to perform intermediary roles and support interaction and learning among the stakeholders to develop complementary understanding of climate change adaptation and approaches for collective action. Seeking support in terms of favorable rules, regulations, and required financial resources from the policy processes are other important tasks on which AERAS providers should focus.

AERAS agencies will likely face challenges in embracing the transformational roles to support innovation for climate change adaptation in the agriculture sector. In this vein, the political context, and the organizational structure and worldviews of AERAS providers are among the many challenges that may need consideration. The plans and priorities of governments often influence the focus and ways of implementing AERAS programs (Berhanu \& Poulton, 2014). Governments require support from the AERAS providers to execute different public policies and interests (Mahon, Farrell, \& McDonagh, 2010), which ultimately might deviate AERAS agencies from their principal modes of action (Diesel \& Miná Dias, 2016).

Conducting organizational reforms of AERAS agencies to embrace agricultural innovation approaches is challenging, especially in developing countries (Hounkonnou et al., 2012; Rivera \& Sulaiman, 2009). The administration and policy-making system of AERAS agencies might be unwilling to reconsider their long-term roles and practices to embrace agricultural innovation approaches (Chowdhury, Odame, \& Leeuwis, 2014). AERAS agencies have shown resistance to consider deep-rooted reform (Islam, Gray, Reid, \& Kemp, 2011). Change in organizational strategies faces political, social, and contextual complexities (Islam et al., 2011). Moreover, gaps often exist between the organizational mandates or vision and the AERAS providers' worldviews (Landini, 2015). In addition, intra- and inter-organizational differences of innovation perception and mindsets are found among AERAS providers. In the same AERAS agency, some individuals might have mindsets largely dominated by top-down approaches emphasizing specialists' knowledge dissemination whereas others might prefer to adopt dialogical approaches and horizontal interaction of knowledge sharing and learning (Landini, 2016).

Overall, a lack of evidence exists from the reviewed literature on how to develop the capacities of AERAS providers to enhance agricultural innovation in the context of climate change. The Tropical Agriculture Platform (2016) proposes four aspects of capacity development, - capacity to navigate complexity, collaborate, reflect and learn, engage in strategic and political processes - to ensure actors' effective involvement in enhancing agricultural innovation in general. These capacities might provide insight on formulating ways to develop functional capacities of AERAS providers to support agricultural innovation for climate change adaptation. However, further research is needed to better understand the means and strategies for developing the capacities of AERAS providers. 
The AERAS professionals, providers, and agencies serving in regions more prone to climate change and working at different scales, could utilize these research insights to better develop strategies for ensuring sustainability in the agriculture sector. However, these findings should not be used as a one-size-fits-all approach. Depending on the local, national, and political contexts, as well as financial and organizational support, AERAS providers are encouraged to reconsider their roles and formulate new ways to enhance agricultural innovation for climate change adaptation in their localities.

\section{Acknowledgements}

The Higher Degree by Research (HDR) fee merit scholarship and HDR research scholarship of the Australian National University are acknowledged for supporting the Doctor of Philosophy study of the first author.

\section{References}

Aase, T. H., Chapagain, P. S., \& Tiwari, P. C. (2013). Innovation as an expression of adaptive capacity to change in Himalayan farming. Mountain Research and Development, 33(1), 4-11. https://doi.org/10.1659/MRD-JOURNAL-D-12-00025.1

Abegaz, D. M., \& Wims, P. (2015). Extension agents' awareness of climate change in Ethiopia. The Journal of Agricultural Education and Extension, 21(5), 479-495. https://doi.org/10.1080/1389224X.2014.946936

Afful, D. B. (2016). Public extension agents' need for new competencies: Evidence from a climate variability study in Limpopo province, South Africa. South African Journal of Agricultural Extension, 44(2), 59-70. Retrieved from https://www.ajol.info/index.php/sajae/article/view/149127

Anderson, J. R. (2007). Agricultural advisory services: Background paper for the world development report 2008. Retrieved from the World Bank website: http://documents.worldbank.org/curated/en/490981468338348743/pdf/413540Anders on1AdvisoryServices01PUBLIC1.pdf

Anita, W., Dominic, M., \& Neil, A. (2010). Climate change and agriculture: Impacts, adaptation and mitigation. Paris, France: The Organisation for Economic Co-operation and Development (OECD) publishing.

Berhanu, K., \& Poulton, C. (2014). The political economy of agricultural extension policy in Ethiopia: Economic growth and political control. Development Policy Review, 32(s2), s197-s213. https://doi.org/10.1111/dpr.12082

Bernard, H. R. (2017). Research methods in anthropology: Qualitative and quantitative approaches (6th ed.). Lantham, MD: Rowman \& Littlefield. 
Chowdhury, A. H., Odame, H. H., Leeuwis, C. (2014). Transforming the roles of a public extension agency to strengthen innovation: Lessons from the national agricultural extension project in Bangladesh. The Journal of Agricultural Education and Extension, 20(1), 7-25. https://doi.org/10.1080/1389224X.2013.803990

Christoplos, I. (2010). Mobilizing the potential of rural and agricultural extension. Retrieved from Food and Agriculture Organization of the United Nations website: http://www.fao.org/3/i1444e/i1444e00.htm

Davis, K. E. (2009). Agriculture and climate change: An agenda for negotiation in Copenhagen. The important role of extension systems (IFPRI Focus 16 Brief 11). Retrieved from Consultative Group for International Agricultural Research (CGIAR) website: http://www.asb.cgiar.org/PDFwebdocs/focus16 11.pdf

Davis, K., \& Sulaiman, V. R. (2016). Note 0: Overview of extension philosophies and methods. GFRAS good practice notes for extension and advisory services. Retrieved from Global Forum for Rural Advisory Services (GFRAS) website: https://www.g-fras.org/en/goodpractice-notes/0-overview-of-extension-philosophies-and-methods.html

Diehl, D. C., Galindo-Gonzalez, S., Dourte, D. R., Sloan, N. L., Bartels, W. L., Furman, C., \& Fraisse, C. W. (2015). Toward engagement in climate training: Findings from interviews with agricultural extension professionals. Journal of Rural Social Sciences, 30(1), 25-50. Retrieved from http://journalofruralsocialsciences.org/pages/Articles/JRSS\%202015\%2030/1/JRSS\%202 015\%2030\%201\%2025-50.pdf

Diesel, V., \& Miná Dias, M. (2016). The Brazilian experience with agroecological extension: A critical analysis of reform in a pluralistic extension system. The Journal of Agricultural Education and Extension, 22(5), 415-433.

https://doi.org/10.1080/1389224X.2016.1227058

Faure, G., Desjeux, Y., \& Gasselin, P. (2012). New challenges in agricultural advisory services from a research perspective: A literature review, synthesis and research agenda. The Journal of Agricultural Education and Extension, 18(5), 461-492. https://doi.org/10.1080/1389224X.2012.707063

Faure, G., Penot, E., Rakotondravelo, J. C., Ramahatoraka, H. A., Dugué, P., \& Toillier, A. (2013). Which advisory system to support innovation in conservation agriculture? The case of Madagascar's Lake Alaotra. The Journal of Agricultural Education and Extension, 19(3), 257-270. https://doi.org/10.1080/1389224X.2013.782169 
Food and Agriculture Organization. (2007). Adaptation to climate change in agriculture, forestry and fisheries: perspective, framework and priorities. Retrieved from http://www.fao.org/3/a-au030e.pdf

Food and Agriculture Organization. (2018). FAO's work on agricultural innovation: Sowing the seeds of transformation to achieve the SDGs. Retrieved from http://www.fao.org/3/CA2460EN/ca2460en.pdf

Gough, D., Oliver, S., \& Thomas, J. (2017). An introduction to systematic reviews ( ${ }^{\text {nd }}$ ed.). Thousand Oaks, CA: Sage.

Hachigonta, S. (2016). Module 13: Risk mitigation and adaptation in extension. The new extensionist learning kit. Retrieved from Global Forum for Rural Advisory Services (GFRAS) website: https://www.g-fras.org/en/knowledge/new-extensionist-learning-kitnelk.html

Hounkonnou, D., Kossou, D., Kuyper, T. W., Leeuwis, C., Nederlof, E. S., Röling, N., \& van Huis, A. (2012). An innovation systems approach to institutional change: Smallholder development in West Africa. Agricultural Systems, 108, 74-83. https://doi.org/10.1016/j.agsy.2012.01.007

Huyer, S., \& Nyasimi, M. (2017). Climate-smart agriculture manual for agriculture education in Zimbabwe. Retrieved from Consultative Group for International Agricultural Research (CGIAR) website: https://ccafs.cgiar.org/publications/climate-smart-agriculture-manualagriculture-education-zimbabwe

Ifejika Speranza, C., Kiteme, B., \& Opondo, M. (2009). Adapting public agricultural extension services to climate change: Insights from Kenya. Retrieved from BORIS database: https://boris.unibe.ch/69717/1/AC2009-0149.pdf

Islam, M. M., Gray, D., Reid, J., \& Kemp, P. (2011). Developing sustainable farmer-led extension groups: Lessons from a Bangladeshi case study. The Journal of Agricultural Education and Extension, 17(5), 425-443. https://doi.org/10.1080/1389224X.2011.596658

Julie, D. T., Amungwa, F. A., \& Manu, I. (2017). Role of agricultural extension in climate change adaptation in Cameroon. International Journal of Horticulture, Agriculture and Food science (IJHAF), 1(3), 21-26. https://doi.org/10.22161/ijhaf.1.3.5

Landini, F. (2015). Different Argentine rural extensionists' mindsets and their practical implications. The Journal of Agricultural Education and Extension, 21(3), 219-234. https://doi.org/10.1080/1389224X.2014.927375 
Landini, F. (2016). Unfolding the knowledge and power dynamics of the 'farmers-rural extensionists' interface in north-eastern Argentina. The Journal of Agricultural Education and Extension, 22(5), 399-413. https://doi.org/10.1080/1389224X.2016.1227050

Leeuwis, C. (2004). Communication for rural innovation: Rethinking agricultural extension. Oxford, England: Blackwell Science Incorporation.

Leeuwis, C., \& Aarts, N. (2011). Rethinking communication in innovation processes: Creating space for change in complex systems. Journal of Agricultural Education and Extension, 17(1), 21-36. https://doi.org/10.1080/1389224X.2011.536344

Leeuwis, C., Hall, A., van Weperen, W., \& Preissing, J. (2013). Facing the challenges of climate change and food security: The role of research, extension and communication for development. Retrieved from Food and Agriculture Organization of the United Nations website: http://www.fao.org/3/a-i3334e.pdf

Mahmoudi, H., \& Knierim, A. (2015). Risk communication for farmers' adaptation to climate change: A new task for agricultural advisory services. International Journal of Performability Engineering, 11(6), 533-547. Retrieved from https://pdfs.semanticscholar.org/476f/5d01a3b9b822327b26eca9b0b0502a3d4234.pdf

Mahon, M., Farrell, M., \& McDonagh, J. (2010). Power, positionality and the view from within: Agricultural advisers' roles in implementing participatory extension programmes in the Republic of Ireland. Sociologia Ruralis, 50(2), 104-120. https://doi.org/10.1111/j.14679523.2010.00505.x

Mkisi, R. B. (2014). The role of agricultural extension in smallholder farmer adaptation to climate change in Blantyre district, Malawi (MS dissertation, Purdue University, West Lafayette, Indiana). Retrieved from https://docs.lib.purdue.edu/dissertations/AAI1585361/

Mustapha, S., Undiandeye, U., \& Gwary, M. (2012). The role of extension in agricultural adaptation to climate change in the Sahelian zone of Nigeria. Journal of Environment and Earth Science, 2(6), 48-58. Retrieved from http://citeseerx.ist.psu.edu/viewdoc/download?doi=10.1.1.933.5124\&rep=rep1\&type=pdf

Neufeldt, H., Negra, C., Hancock, J., Foster, K., Nayak, D., \& Singh, P. (2015). Scaling up climatesmart agriculture: Lessons learned from South Asia and pathways for success. Retrieved from World Agroforestry Centre website: http://www.worldagroforestry.org/downloads/Publications/PDFS/WP15720.pdf

Ngwenya, H., \& Hagmann, J. (2011). Making innovation systems work in practice: Experiences in integrating innovation, social learning and knowledge in innovation platforms. Knowledge Management for Development Journal, 7(1), 109-124. https://doi.org/10.1080/19474199.2011.593867 
Ogunbameru, B., Mustapha, S., \& Idrisa, Y. (2013). Capacity building for climate change adaptation: Modules for agricultural extension curriculum development. Russian Journal of Agricultural and Socio-Economic Sciences, 14(2), 61-66. Retrieved from https://pdfs.semanticscholar.org/2d1d/94b53e9cf4f5d8ce9df5d8db2936cd4dedd3.pdf

Ozor, N., \& Cynthia, N. (2011). The role of extension in agricultural adaptation to climate change in Enugu state, Nigeria. Journal of Agricultural Extension and Rural Development, 3(3), 42-50. Retrieved from http://www.academicjournals.org/app/webroot/article/article1379426712 Ozor\%20an d\%20Nnaji.pdf

Rajalahti, R., Janssen, W., \& Pehu, E. (2008). Agricultural innovation systems: From diagnostics toward operational practices. Retrieved from the World Bank website: http://wwwwds.worldbank.org/external/default/WDSContentServer/WDSP/IB/2008/05/02/000334 955 20080502052523/Rendered/PDF/434350NWP0ARDD1Box0327368B01PUBLIC1.pdf

Rivera, W. M., \& Sulaiman, V. R. (2009). Extension: Object of reform, engine for innovation. Outlook on Agriculture, 38(3), 267-273. https://doi.org/10.5367/000000009789396810

Sala, S., Rossi, F., \& David, S. (2016). Supporting agricultural extension towards climate-smart agriculture: An overview of existing tools. Compendium climate-smart agriculture \& extension. Retrieved from Food and Agriculture Organization of the United Nations website: http://www.fao.org/3/a-bl361e.pdf

Selvaraju, R. (2012). Climate risk assessment and management in agriculture. In A. Meybeck, J. Lankoski, S. Redfern, N. Azzu, \& V. Gitz (Eds.), Building resilience for adaptation to climate change in the agriculture sector. Proceedings of a Joint FAO/OECD Workshop (pp. 71-90). Rome, Italy.

Sharma, R., Peshin, R., Khar, S., \& Ishar, A. K. (2014). Agriculture innovation system approach for sustainable agriculture development: A review. Agro Economist, 1(1), 1-7. Retrieved from https://pdfs.semanticscholar.org/30b4/4d1c33f708645452e6615e21ba6c01da1802.pdf

Simpson, B. M. (2016). Pocket guide 1: Extension practice for agricultural adaptation. Preparing smallholder farm families to adapt to climate change. Retrieved from: https://www.crs.org/sites/default/files/tools-research/pocket-guide-1.pdf

Simpson, B. M., \& Burpee, C. G. (2014). Adaptation under the "new normal" of climate change: The future of agricultural extension and advisory services. Retrieved from: https://agrilinks.org/sites/default/files/resource/files/MEAS\%20Discussion\%20Paper\%2 03\%20-\%20Climate\%20Change\%20and\%20EAS\%20-\%202014 01 31.pdf 
Spielman, D. J., Davis, K., Negash, M., \& Ayele, G. (2011). Rural innovation systems and networks: Findings from a study of Ethiopian smallholders. Agriculture and Human Values, 28(2), 195-212. Retrieved from https://link.springer.com/article/10.1007/s10460-010-9273-y

Stål, H. I., \& Bonnedahl, K. J. (2015). Provision of climate advice as a mechanism for environmental governance in Swedish agriculture. Environmental Policy and Governance, 25(5), 356-371. https://doi.org10.1002/eet.1677

Sulaiman, R. V. (2017). Enabling advisory services for climate-smart agriculture: Key elements to foster farmers' adoption of CSA practices. Policy brief enabling advisory services for CSA. Retrieved from Food and Agriculture Organization of the United Nations website: http://www.fao.org/3/a-bs940e.pdf

Sulaiman, R. V., Chuluunbaatar, D., \& Vishnu, S. (2018). Upscaling climate smart agriculture: Lessons for extension and advisory services. Retrieved from Food and Agriculture Organization of the United Nations website: http://www.fao.org/uploads/media/Climate_Smart_Agriculture_draft08.pdf

Tropical Agriculture Platform. (2016). Common framework on capacity development for agricultural innovation systems: Guidance note on operationalization. Wallingford, England: Centre for Agriculture and Bioscience International (CABI).

World Bank. (2006). Enhancing agricultural innovation: How to go beyond the strengthening of research systems. Retrieved from http://documents.worldbank.org/curated/en/864351468325269468/pdf/379000Enhan cin1010FFICIALOUSEOONLY1.pdf

World Bank. (2012). Agricultural innovation systems: An investment sourcebook. Retrieved from https://openknowledge.worldbank.org/handle/10986/2247

Wright Morton, L., Prokopy, L. S., Arbuckle, J. G., Ingels, C., Thelen, M., Bellm, R., ... Widhalm, M. (2016). Climate change and agricultural extension: Building capacity for land grant extension services to address the agricultural impacts of climate change and the adaptive management needs of agricultural stakeholders. Retrieved from the Extension Store, Extension and Outreach, lowa State University website: https://store.extension.iastate.edu/product/14504

Yami, M., Vogl, C., \& Hausera, M. (2009). Comparing the effectiveness of informal and formal institutions in sustainable common pool resources management in Sub-Saharan Africa. Conservation and Society 7(3), 153-164. https://doi.org/10.4103/0972-4923.64731

(c) 2020 by authors. This article is an open access article distributed under the terms and conditions of the Creative Commons Attribution license (http://creativecommons.org/licenses/by/4.0/). 